\title{
Crafting a Wine Business Case Study and Its Teaching Note: Guidance for Research and Publication
}

$\mathrm{T}$ his paper will attempt to open a dialogue about the elements that constitute an outstanding wine business case study and, if used for teaching purposes, an instructor's manual. The ability to understand, synthesize, evaluate, and also create cases is becoming an increasingly important career-building skill for graduates of higher education programs across all disciplines. Case studies about wine businesses can help achieve mastery of program learning outcomes and begin to close the loop (Alexander, 2011). Numerous wine business program graduates have reported that adding evidence of their ability to create, review, or analyze cases to their "job search portfolios” had given them "an edge over other candidates" for a position.

\section{STEP 1-PLANNING}

The initial step in planning a wine business case study (“case”) involves deciding its purpose or ultimate use. A case can be intended for some research purpose i.e., to build or refute theory via comparative case analyses (Eisenhardt and Graebner, 2007; Sigglekow, 2007; Yin, 1994). Alternatively, a case can be developed for teaching purposes, i.e., to illustrate or derive theory in a classroom setting that involves a dialectical discussion to identify problems or challenges facing an organization and then generate and choose among solutions. In some instances, authors can craft a case that will satisfy both objectives, i.e. one might compare multiple teaching cases to build theory (cf. Gilinsky et al. 2008, 2010; Lawrence, 2010).

Aside from the differentiation between a case developed with a research purpose in mind and a case developed with the illustration of a theory in mind, there are also decision cases as compared to evaluative (sometimes called "discussion cases"). A decision case allows the student to internalize a real decision that an actor in the case must make and develop and support a solution for that decision. An evaluative case, on the other hand, presents information about a particular situation or event that has occurred in the past in an organization and allows the discussants to reflect upon the actions taken to learn lessons from the decisions made. This type of case can also be used to develop theory. One disadvantage of discussion or evaluative cases is

This guidance paper was prepared for the Wine Business Case Research Journal by Armand Gilinsky, Jr., Sonoma State University; Sharon L. Forbes, Lincoln University; and Marlene M. Reed, Baylor University. 
that a number of journals only publish cases that are decision focused. Exhibit $\mathbf{1}$ is a representative list of case journals.

\section{Exhibit 1}

A Representative List of Peer-Reviewed Case Journals

\begin{tabular}{|c|c|c|c|c|}
\hline Name of Journal & Sponsor & $\begin{array}{l}\text { Accepts Only } \\
\text { Decision Cases }\end{array}$ & $\begin{array}{l}\text { Accepts Both } \\
\text { Decision \& } \\
\text { Discussion } \\
\text { Cases } \\
\end{array}$ & $\begin{array}{l}\text { Primary } \\
\text { Focus }\end{array}$ \\
\hline $\begin{array}{l}\text { Wine Business Case } \\
\text { Research Journal }\end{array}$ & $\begin{array}{l}\text { Sonoma State University } \\
\text { Wine Business Institute }\end{array}$ & $\mathrm{X}$ & & $\begin{array}{l}\text { Cases dealing with the } \\
\text { wine industry }\end{array}$ \\
\hline Case Research Journal & $\begin{array}{l}\text { North American Case } \\
\text { Research Assoc. }\end{array}$ & $\mathrm{X}$ & & All business disciplines \\
\hline The Case Journal & $\begin{array}{l}\text { The Case } \\
\text { Association }\end{array}$ & & $\mathrm{X}$ & $\begin{array}{l}\text { All business } \\
\text { disciplines }\end{array}$ \\
\hline $\begin{array}{l}\text { The Journal of Applied } \\
\text { Case Research }\end{array}$ & $\begin{array}{l}\text { Southwest Case Research } \\
\text { Association }\end{array}$ & & $\mathrm{X}$ & $\begin{array}{l}\text { All business } \\
\text { disciplines }\end{array}$ \\
\hline $\begin{array}{l}\text { The Journal of Finance } \\
\text { Case } \\
\text { Research }\end{array}$ & $\begin{array}{l}\text { Institute of } \\
\text { Finance Case } \\
\text { Research }\end{array}$ & & $\mathrm{X}$ & Finance and Economics \\
\hline $\begin{array}{l}\text { The Journal of Ethics \& } \\
\text { Entrepreneurship }\end{array}$ & $\begin{array}{l}\text { The Center for Ethics \& } \\
\text { Entrepreneurship, } \\
\text { Gardner-Webb University }\end{array}$ & & $\mathrm{X}$ & $\begin{array}{l}\text { The intersection of ethics } \\
\text { \& entrepreneurship }\end{array}$ \\
\hline $\begin{array}{l}\text { The Journal of Business } \\
\text { Ethics Education }\end{array}$ & $\begin{array}{l}\text { Neilson Journal } \\
\text { Publishing }\end{array}$ & & $\mathrm{X}$ & Ethics \\
\hline
\end{tabular}

Source: Authors of this paper.

\section{STEP 2-SELECTING A TOPIC}

Once you have decided upon the ultimate use of your case, put together a list of three-to-five major learning objectives and relevant interview questions tied to those objectives. It also makes good sense to tie your primary (field) and secondary (library or electronic database) research objectives to your program or school's learning objectives. See Exhibit 2 for five sample topics: (1) Goals, (2) Business model, (3) Situational environment, (4) Stakeholders, and (5) Assumptions and key metrics. 
Exhibit 2

Sample Topics for a Wine Business Case

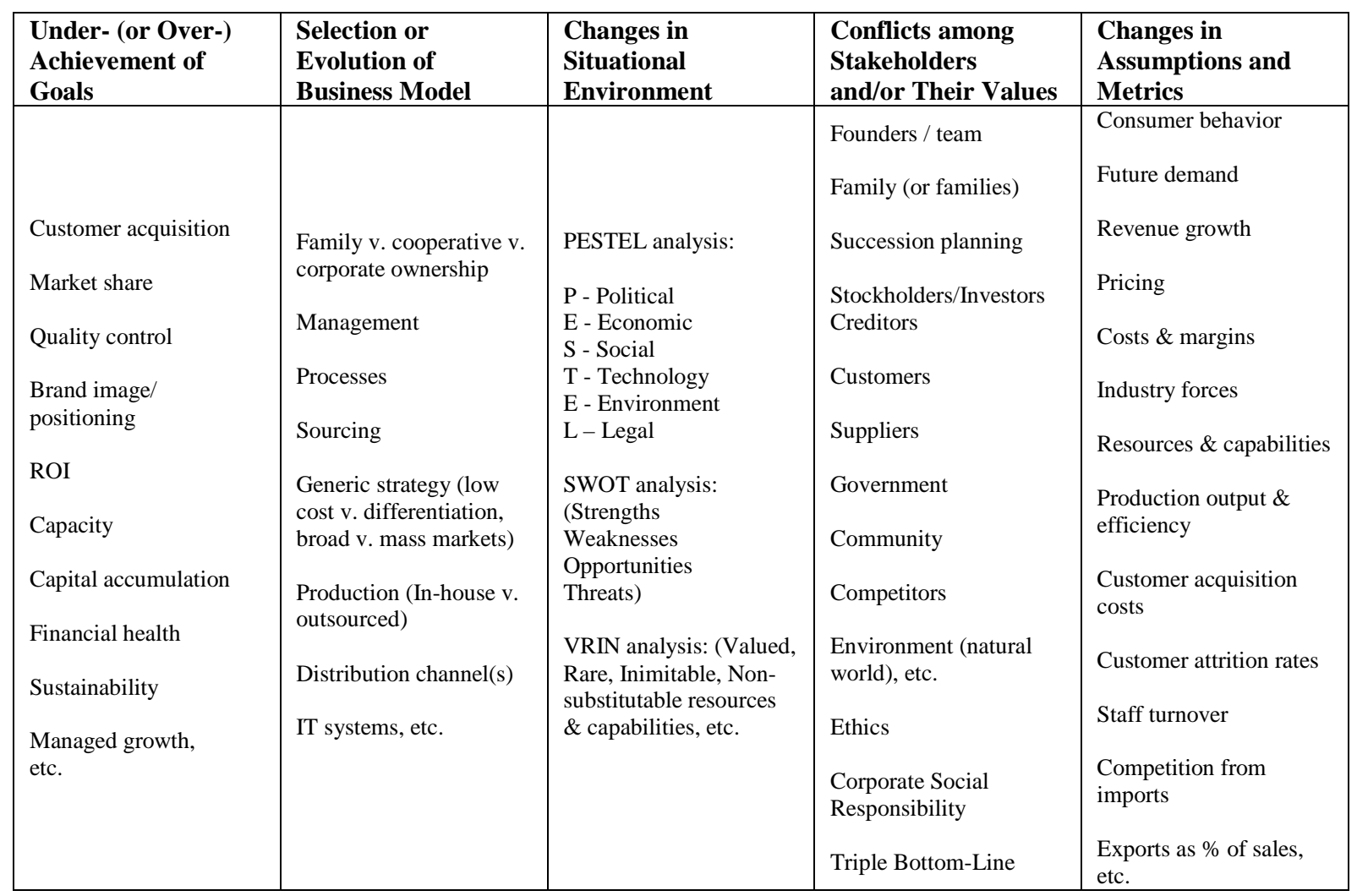

Source: Authors of this paper.

Under- (or over-) achievement of goals. This is generally a good topic to get your case research underway, and to get at this issue, you might ask your case client (wine producer or support organization such as a bank, cooperage, tourism provider, distributor, etc.) about some of the major changes it has undergone over the years since that business was founded. Much in the wine industry has changed since most participants in that industry were born! Your case client's evolution over time may also illustrate the change from a family managed to a professionally managed business, or on a more macro level, the maturation of the wine industry sector itself, all reflective of shifting emphases over time. Your case could also show how your case client's top management team's strategies and leadership styles have changed to match changing situations over time (Churchill and Lewis, 1989; Daily and Dollinger, 1994; Greiner, 1972). Exhibit 3 illustrates how one winery, Beringer Wine Estates, evolved in the years since 1876, when it was founded by German immigrants in Napa, California. 
Exhibit 3

Evolution of Beringer Wine Estates, 1875-present

\begin{tabular}{|c|c|c|c|c|}
\hline Dates & Ownership & Situation & Style & Strategy \\
\hline 1876 (founding) - 1970 & Beringer family & $\begin{array}{l}\text { Agrarian nation; major } \\
\text { wave of European } \\
\text { immigrants; post- } \\
\text { Industrial revolution }\end{array}$ & $\begin{array}{l}\text { Family business, small } \\
\text { business, agrarian }\end{array}$ & $\begin{array}{l}\frac{\text { Prospector }}{\text { Early market entry in }} \\
\text { US. (St. Helena, CA); } \\
\text { local/regional scope }\end{array}$ \\
\hline $\begin{array}{l}1970-1986 \\
\text { (Wine World Estates) }\end{array}$ & Conglomerate-Nestlé & $\begin{array}{l}\text { Growth in jug wine } \\
\text { segments }\end{array}$ & $\begin{array}{l}\text { Professional, } \\
\text { economists \& } \\
\text { marketers }\end{array}$ & $\begin{array}{l}\text { Reactor } \\
\text { Subsidiary of MNC; } \\
\text { leverage into national } \\
\text { mass-market } \\
\text { distribution }\end{array}$ \\
\hline 1996-1997 & Private (via LBO) & $\begin{array}{l}\text { Double-digit growth in } \\
\text { premium wine } \\
\text { segments; increased } \\
\text { acceptance of wineries } \\
\text { in public equities } \\
\text { markets }\end{array}$ & Entrepreneurial & $\begin{array}{l}\text { Prospector } \\
\text { Re-invent company in } \\
\text { premium wine } \\
\text { segments }\end{array}$ \\
\hline $1997-2000$ & Public (via IPO) & $\begin{array}{l}\text { Fragmented market; } \\
\text { entry of Australian } \\
\text { wineries into global } \\
\text { markets }\end{array}$ & $\begin{array}{l}\text { Professional; } \\
\text { opportunistic }\end{array}$ & $\begin{array}{l}\text { Analyzer } \\
\text { Growth via acquisition } \\
\text { and diversification of } \\
\text { low-end segments }\end{array}$ \\
\hline 2000-present & $\begin{array}{l}\text { Conglomerate - } \\
\text { Foster's } \\
\text { Group/Treasury Wine } \\
\text { Estates (TWE) }\end{array}$ & $\begin{array}{l}\text { Constant growth in } \\
\text { premium segment; } \\
\text { consolidation and } \\
\text { maturity of trade } \\
\text { channels; merger with } \\
\text { Mildara Blass; spin-off } \\
\text { from Fosters' Group } \\
\text { into TWE }\end{array}$ & $\begin{array}{l}\text { Professional, } \\
\text { economists \& } \\
\text { marketers }\end{array}$ & $\begin{array}{l}\text { Defender } \\
\text { Operating unit of MNC; } \\
\text { leverage into global } \\
\text { mass-market } \\
\text { distribution }\end{array}$ \\
\hline
\end{tabular}

Source: Authors of this paper.

Selection or evolution of a business model. Business models and how they have been adopted specifically in the wine industry are ripe topics for case authors. Business models often involve supply chain choices, degree of integration, and selection of distribution channel(s). For example, authors may want to illustrate the advantages and disadvantages of various business models, i.e., wineries are either partially integrated, fully integrated, or "virtual." Exhibit 4 lists some of the pros and cons of the virtual and fully integrated winery business models.

\section{Exhibit 4}

Pros and Cons of Winery Integration Options

\begin{tabular}{|c|c|}
\hline \multicolumn{2}{|l|}{ Virtual Winery } \\
\hline Pros: & Cons: \\
\hline Lower capital requirements & No winery for customers to visit \\
\hline More flexibility to adjust to trends & Long-term assets are mostly intangible \\
\hline Shorter delay before earning revenue & More difficult to build a "story" to tell \\
\hline Lower operating risk due to decreased fixed costs & Lower contribution margin on incremental sales \\
\hline
\end{tabular}




\begin{tabular}{|l|l|}
\hline \multicolumn{2}{|l|}{ Bricks \& Mortar Winery } \\
\hline Pros: & Cons: \\
$\begin{array}{l}\text { Winery has a sense of place } \\
\begin{array}{l}\text { Uptential for appreciation of asset value, especially land and } \\
\text { buildings }\end{array}\end{array}$ & $\begin{array}{c}\text { Delay from incurring first costs to earning revenue, especially } \\
\text { with vineyards }\end{array}$ \\
$\begin{array}{l}\text { Customer visits may build brand loyalty } \\
\text { Higher contribution margin on incremental sales }\end{array}$ & \begin{tabular}{l} 
Higher operating risk due to increased fixed costs. \\
\hline
\end{tabular}
\end{tabular}

Source: Authors of this paper.

Changes in the situational environment. Wine businesses might well be characterized, to paraphrase former Sony CEO Akio Morita (1986), "[as] inheritors of a rich agrarian cultural tradition and philosophy, which are influenced by nature and change of the seasons,” i.e., by analog thinking and slow motion. While the wine industry has heretofore experienced slow evolution (Cooper, 2007), recently, some players have pursued innovative strategies. Some innovations that may become interesting case topics include: sustainable farming techniques such as organic and biodynamic agriculture; specific varietal (vs. blended) products; packaging other than glass bottles and closures other than corks; market re-segmentation from two major price tiers to multiple tiers and into emerging demographic or lifestyle categories such as "GenX" or the "Millennials;" new marketing approaches such as "lifestyle” brand names, wine clubs, fair trade and organic product labeling, use of the Internet to promote information and, in some instances, direct sales; and, in selected cases, the emergence of new organization structures i.e., 'virtual' wineries. Yet most players in the wine industry have not yet adopted these innovations, either in total or in part, nor do they have plans to do so in the near future (Jordan, Zidda, and Lockshin, 2007).

Authors may want to focus on brand development in a domestic or a global context. A productdriven company is one that aims to make the best product possible and differentiates itself on the basis of quality. In striving for quality, the raw materials selected are critical. For a winery, this would be the grapes, barrels, etc. Some other descriptors of a product-driven company could include: high-cost production, price-resistant products, recognized origins or terroir, production limited by quality, quality/brand relationship, and/or lower sales and marketing costs than rivals. Use of the "Hierarchy of Differentiation" (Huneeus, 2001) is key to product-driven wineries. Huneeus (2001, p. 101-102) indicates that, in order to sustain product differentiation, a winery must build a big brand image. There is a hierarchy that wineries can evolve through, as the product class gets smaller. Each further classification adds to a wine producer's ability to differentiate. An outline of this hierarchy appears in Exhibit 5. 


\section{Exhibit 5}

Huneeus's Hierarchy of Wine Business Differentiation

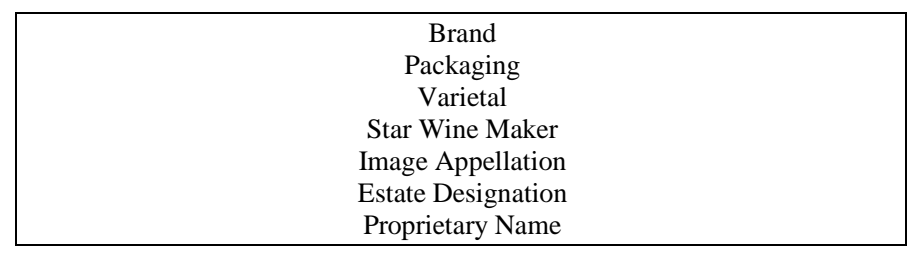

Source: Huneeus (2001), p. 102.

However, since many students and practitioners lack multinational business experience, let alone managerial experience growing ventures in a diversified context, some case authors may want to illustrate the benefits and limits of operating in a global context. One way to do so is to consider strategic issues on the country level, corporate level, and business level, as follows:

1) To illustrate country-level strategy, design your case to examine the dynamics of competition among the "new-world" wine producers in Australia and California as well as other wineproducing countries (Porter, 1990).

2) To illustrate corporate-level strategy, design your case to create a dialogue over the benefits and limits of international, multi-domestic, global, and transnational strategies (Harrison et. al. 2001).

3) To illustrate business-level strategy, design your case to spark a debate over whether Winery $\mathrm{X}$ should focus on internal (organic) growth of its brands v. external growth via acquisitions. Illustrate some of the challenges associated with creating a "center of excellence," i.e., achieving synergies among globally diversified product lines such as branded products, hospitality, and events (Palich and Gomez-Mejia, 1999).

The appropriateness of those strategies varies given the extent of pressures for cost reductions and local responsiveness (Bartlett and Ghoshal, 1989). International and global strategies tend to be least appropriate in markets where local responsiveness to consumer tastes is important (e.g. in consumer food and beverage products industries, with the possible exception of sodas, beer, and spirits). At the same time, in the wine industry, competitive conditions are so intense that to survive, companies must essentially do all they can to respond to pressures for cost reductions and local responsiveness. Exhibit 6 illustrates some of the advantages and disadvantages of different strategies for competing globally and applies those to Winery X's situation. Yet changing a company's business model to build an organization capable of supporting a transnational strategy is a complex and challenging task: implementation problems associated with creating the requisite organizational structure and control systems have been well documented (Palich and Gomez-Mejia, 1999). 
Exhibit 6

Global Strategic Alternatives for A Wine Business

\begin{tabular}{|c|c|c|c|}
\hline Strategy & Advantages & Disadvantages & Winery X's Strategy \\
\hline International & $\begin{array}{l}\text { Transfer of distinctive } \\
\text { competencies to foreign } \\
\text { markets }\end{array}$ & $\begin{array}{l}\text { Lack of local responsiveness } \\
\text { Inability to realize location } \\
\text { economies } \\
\text { Failure to exploit experience- } \\
\text { curve effects }\end{array}$ & $\begin{array}{l}\text { Does not respond to need for } \\
\text { cost reductions } \\
\text { Does not respond to pressures } \\
\text { for local responsiveness in } \\
\text { wine segment }\end{array}$ \\
\hline Multi-domestic & $\begin{array}{l}\text { Ability to customize product } \\
\text { offerings and marketing in } \\
\text { accordance with local } \\
\text { responsiveness }\end{array}$ & $\begin{array}{l}\text { Inability to realize location } \\
\text { economies } \\
\text { Failure to exploit experience- } \\
\text { curve effects } \\
\text { Failure to transfer distinctive } \\
\text { competencies to foreign } \\
\text { markets }\end{array}$ & $\begin{array}{l}\text { Meets need for localization in } \\
\text { wine segment but does not } \\
\text { address need for cost } \\
\text { reductions }\end{array}$ \\
\hline Global & $\begin{array}{l}\text { Ability to exploit experience- } \\
\text { curve effects } \\
\text { Ability to realize location } \\
\text { economies }\end{array}$ & Lack of local responsiveness & $\begin{array}{l}\text { Makes sense for beer segment } \\
\text { but not (yet) for wine segment } \\
\text { May be driven by pressures for } \\
\text { cost reductions }\end{array}$ \\
\hline Transnational & $\begin{array}{l}\text { Ability to exploit experience- } \\
\text { curve effects } \\
\text { Ability to: exploit location } \\
\text { economies, customize product } \\
\text { offerings and marketing to } \\
\text { afford local responsiveness, } \\
\text { and reap benefits of local } \\
\text { learning }\end{array}$ & $\begin{array}{l}\text { Difficulties in implementation } \\
\text { because of organizational } \\
\text { problems }\end{array}$ & $\begin{array}{l}\text { Logical -- given pressures for } \\
\text { cost reductions and local } \\
\text { responsiveness }\end{array}$ \\
\hline
\end{tabular}

Sources: Adapted from Bartlett \& Ghoshal (1989), Hill \& Jones (2004).

Conflicts (or cohesion) among key stakeholders. There are multiple stakeholders involved in a winery supply chain, from suppliers to creditors to owners to staff, etc. Case authors should strongly consider presenting a 360-degree view of an organization using either multiple voices or multiple viewpoints to show how conflict is managed and consensus is gained. Most wineries are small, family-owned businesses, and members of families can often come into conflict over challenges such as the pace of growth, innovation, and succession planning. For all wine businesses, regardless of management or ownership, there may be disagreements with (or among) various actors, including staff, communities, creditors, and so forth. See Exhibit $\mathbf{7}$ for examples of stakeholder expectations and needs. 
Exhibit 7

Identifying and Managing Stakeholders’ Expectations

\begin{tabular}{|c|c|c|}
\hline Stakeholder & Stakeholder's Expectations & If unmet? \\
\hline Employees & $\begin{array}{l}\text { Let's work together } \\
\text { We want stable employment and fair compensation } \\
\text { We want to be treated fairly }\end{array}$ & We can work elsewhere... \\
\hline Customers & $\begin{array}{l}\text { We want you to meet our needs for quality and safety } \\
\text { We'll both receive value }\end{array}$ & We can buy elsewhere... \\
\hline Suppliers & $\begin{array}{l}\text { We want to be paid on time } \\
\text { We want information and repeat business } \\
\text { Let's form an alliance }\end{array}$ & We can sell elsewhere... \\
\hline Creditors & We want principal and interest to be paid back on time & We can seize your assets... \\
\hline $\begin{array}{l}\text { Stockholders/ } \\
\text { investors }\end{array}$ & $\begin{array}{l}\text { We want you to protect and grow our investment } \\
\text { We want you to become the industry leader }\end{array}$ & We can withdraw support... \\
\hline Environment & $\begin{array}{l}\text { Obey the rules } \\
\text { Environment comes first }\end{array}$ & Mother Nature bats last... \\
\hline Competitors & $\begin{array}{l}\text { We are all in this together } \\
\text { We can build an industry }\end{array}$ & We will overtake you... \\
\hline Government & We want you to comply with regulations & We can close your operation... \\
\hline Community & You have a responsibility & "Not in my backyard" \\
\hline
\end{tabular}

Source: adapted from Clarkson (1995)

Changes in assumptions or key metrics. One possible objective of a wine business case is to facilitate exposition of a hypothetical winery's - Napa Winery X's — portfolio options. Exhibit 8 compares characteristics of its varietal wines. 


\section{Exhibit 8}

Analysis of Napa Winery X's Varietal Wine Portfolio

\begin{tabular}{|c|c|c|}
\hline Portfolio varietal (color) & Pros & Cons \\
\hline Cabernet Sauvignon (red) & $\begin{array}{l}\text { Highest volume super-premium/luxury wine } \\
\text { Higher growth in demand for red wines } \\
\text { Higher margins than all others except red blends } \\
\text { Cult status of high-end Napa appellation wines }\end{array}$ & $\begin{array}{l}\text { Long cycle from planting to sale \& high } \\
\text { inventory carrying costs } \\
\text { Unknown if demand has peaked for this } \\
\text { varietal }\end{array}$ \\
\hline Chardonnay (white) & $\begin{array}{l}\text { Highest volume among all wine segments } \\
\text { Status of Russian River appellation wines }\end{array}$ & $\begin{array}{l}\text { Low gross margin } \\
\text { Flat demand } \\
\text { Not currently sourced in Napa }\end{array}$ \\
\hline Meritage (and other red blends) & $\begin{array}{l}\text { Expensive - demand limited to connoisseurs and } \\
\text { core drinkers } \\
\text { Highest margin wine }\end{array}$ & $\begin{array}{l}\text { Unknown future demand } \\
\text { Requires Association membership to be } \\
\text { called "Meritage" }\end{array}$ \\
\hline Sauvignon Blanc (white) & $\begin{array}{l}\text { Shortest cycle time to generate cash flow } \\
\text { Grapes less expensive } \\
\text { Demand currently exceeds supply } \\
\text { High gross margin }\end{array}$ & $\begin{array}{l}\text { Flat to modest growth in demand } \\
\text { Low market share }\end{array}$ \\
\hline Zinfandel (red) & $\begin{array}{l}\text { Cult status \& support from ZAP } \\
\text { Low priced relative to other portfolio wines } \\
\text { High past growth rates } \\
\text { Demand currently exceeds supply }\end{array}$ & $\begin{array}{l}\text { Low market share } \\
\text { Rising prices for Napa grapes } \\
\text { Demand may have already peaked }\end{array}$ \\
\hline Petite Sirah (red) & $\begin{array}{l}\text { Cult status \& support from P.S. I Love You } \\
\text { Low priced relative to other portfolio wines } \\
\text { Fastest growing segment } \\
\text { Demand currently exceeds supply }\end{array}$ & $\begin{array}{l}\text { Low market share } \\
\text { Lowest gross margin of all varietal wines } \\
\text { Rising prices for Napa grapes } \\
\text { Unknown future demand }\end{array}$ \\
\hline
\end{tabular}

Source: Authors of this paper.

\section{STEP 3-WRITING YOUR CASE AND TEACHING NOTE}

Ok, so now that you have your topic and objectives in mind, it is time to get started. Exhibit 9 is intended to guide authors who are ready to embark on a wine business case project. 


\section{Exhibit 9 \\ What Authors Need To Do To Create A Written (or Digital) Case}

\section{Begin with your learning objectives}

- Lay out your instructor's manual before you begin - 3-5 learning objectives, linkages to applicable theory, and questions for discussion

- Show how the learning objectives (LOs) match up with your program's LOs and/or course LOs

- $\quad$ List the salient evidence and data that need to be collected (and possible sources of those) in order to meet the above objectives

\section{Outline your primary and secondary research strategies in advance}

- Obtain written permissions to conduct field research

- Decide whether or not you will need to impose organizational, character, and/or data disguises

- Plan for both structured and un-structured interviews

- Cite source materials and acknowledgements

- Create a contingency plan in case the case client or protagonist suddenly becomes unavailable or is unwilling to proceed through a possibly lengthy testing and review process.

\section{Make decisions about content before you create it}

- Decide whether or not you really need a completely written (or digital) case, a hybrid case incorporating both a written and a digital case, or just an audio-visual supplement to a written narrative

- Decide how you plan to ensure access to content for students with disabilities

- Decide if you want your case to be accessible on mobile devices, which could require:

o Use of high-definition video capture technology

o Use of high quality audio capture technology

o Development of a shorter (e.g., $<10$ minute) case or a case in multiple short segments better suited for viewing on small mobile devices

- Prepare a storyboard (Note: PowerPoint is well suited for this task) and, if it is a digital case, prepare a written narrative script, at least in outline form

- Make clear separations between the story and the case analysis in the teaching note or Instructor's Manual (IM)

Test your case with students and colleagues before you submit for publication

- Test with live audiences and observe or ask for feedback about:

o Logic of the narrative arc

0 Length of the narrative

0 Understanding of the case decision

o Awareness of the alternatives under consideration

o Gaps in character development

o The need for other stakeholders' voices

o Comprehension of data and information (e.g., Too little? Too much? Just right?)

o Clarity of sound and images if multimedia are used

$0 \quad$ Need for subtitles or closed captioning if multimedia are used

o Reliability of narration, e.g., any biases communicated by the narrator

o Appropriateness of any ambient sound or music in between interviews if multimedia are used

- Re-capture, re-edit, and test with audiences at least once more before classroom use or submission for an assignment or for publication

Source: Prepared by the authors for this paper.

Build a narrative arc. As a guide to preparing a wine business case, authors can use a more or less standard case-study format that includes five sections: 1) the strategic crisis or challenge (and its urgency); 2) an industry overview; 3) company background; 4) alternatives; and 5) future 
directions or options. ${ }^{1}$ One of the great advantages to case writers inured to print media and to criticism about verb tensing issues, is that a digital media case - unless it is performed by actors using scripts to simulate a "live” performance — is automatically set in the past!

Develop a separate teaching note (also known as an instructor's manual). An instructor's manual is not only necessary to qualify your case as being an intellectual contribution, but also can be very helpful to market your case to other professors and programs. The case analysis or instructor's manual should at a minimum demonstrate the contribution of your work to researchers and practitioners. Has your case depicted an organization that is acting in consonance with what previous theorists have believed to be true, is it instead an outlier, or is new theory needed to explain those behaviors? Your instructor's manual should cover the following topics: (1) Synopsis of the case (i.e., 30-90-second "teaser" if created using multimedia); (2) Research methodologies used in gathering primary and secondary data for the case; (3) Learning objectives and potential contribution of the case to knowledge; (4) Theoretical foundation for the case and case analysis; and (5) Questions posed in developing the case, a rationale for those questions, and suggested answers to those questions with evidence and data to support. Consider framing the questions in a sequence from "Describe this..." to "Evaluate something using a tool..." and then "Recommend an approach based on the following criteria...." An Epilogue may be appended, in either digital or written format (i.e., as a case supplement or handout), depending upon your budget and time available for the project.

\section{For further reading}

Alexander, B. (2011) The New Digital Storytelling: Creating narratives with new media, Chapter 14, "Digital Storytelling in Education,” Santa Barbara, CA: Praeger.

Bartlett, C. A \& Ghoshal, S. (1989) Managing Across Borders: the transnational solution. Boston: Harvard Business School Press.

Churchill, N. C. \& Lewis, V. L. (1989) The five stages of small business growth. In H. Stevenson \& W. Sahlman (Eds.) The Entrepreneurial Venture, pp. 263-275. Boston: Harvard Business School Press.

Clarkson, M. B. E. (1995) A stakeholder framework for analyzing and evaluating corporate social performance. Academy of Management Review, 20(1), 92-117.

Cooper, B. (2007) Just-drinks' Review of 2007: Management Briefing: Wine, December, 10-16.

Daily, C. M. \& Dollinger, M. J. (1994) An empirical examination of ownership structure in family and professionally-managed firms. Family Business Review, 5(2), 117-136.

\footnotetext{
${ }^{1}$ Numerous articles and books on case writing provide variants on this approach. See Kirby et al. (2010: 207), Naumes and Naumes (2012: 129), and Vega (2015: 61-69) for guidance on alternative narrative approaches.
} 
Eisenhardt, K. M. \& Graebner, M. E. (2007) Theory building from cases: opportunities and challenges. Academy of Management Journal, 50(1), 25-32.

Gilinsky, A., Lopez, R.H., Santini, C., \& Eyler, R. (2010) Big Bets, Small Wins? Entrepreneurial behavior and ROI. International Journal of Wine Business Research, 22(3), 238-250.

Gilinsky, A., Santini, C., Lazzerretti, L., \& Eyler, R. (2008) Desperately seeking serendipity: Exploring the impact of country location on innovation in the wine industry. International Journal of Wine Business Research, 20(4), 302-320.

Gimeno, J. \& Woo, C. Y. (1999) Multimarket contact, economies of scope, and firm performance. Academy of Management Journal, 42(3), 239-264.

Greiner, L. A. (1972) Evolution and revolution as organizations grow. Harvard Business Review, July-August, 37-46.

Harrison, J. S., Hitt, M. A., Hoskisson, R. E., \& Ireland, R. D. (2001) Resource complementarity in business combinations: extending the logic to organizational alliances. Journal of Management, 27(6) (Nov-Dec), 679-691.

Hill, C. W. L. \& Jones. G. R. (2004) Strategic management: an integrated approach, 6/E. Boston: Houghton Mifflin, Chapter 8 (“Strategy in the global environment”).

Huneeus, A.F, edited by Moulton, K. and Lapsley, J. (2001) Successful Wine Marketing, Gaithersburg, MD: Aspen Publishers, Inc.

Jordan, R., Zidda, P., Lockshin, L. (2007) Beyond the Australian wine industry’s success. Does environment matter? International Journal of Wine Business Research, 19(1), 14-32.

Kirby, E. G., Ross, J. K., Middlebrook, B. J., Low, R., and Keefe, M. J. (2010) The pedagogy of writing case studies: a grounded learning approach, Journal of Strategic Management Education, 6(3), 199-212.

Lawrence, A. T. (2010) Managing disputes with nonmarket stakeholders: wage a fight, withdraw, wait, or work it out? California Management Review, 53(1), 90-113.

Morita, A. \& Reingold, R. (1986) Made in Japan, E. P. Dutton \& Company, 279.

Naumes, W. \& Naumes, M. (2012) The Art and Craft of Case Writing, $3^{\text {rd }}$ edition, Armonk, NY: M. E. Sharpe.

Palich. L. E. \& Gomez-Mejia, L. R. (1999) A theory of global strategy and firm efficiencies: considering the effects of cultural diversity. Journal of Management, 25(4) (July), 587-607.

Porter, M. E. (1985) Competitive Advantage: creating and sustaining superior performance, New York: Free Press.

Porter, M. E. (1990) The Competitive Advantage of Nations, New York: Free Press. 
Sigglekow, N. (2007) Theory building from cases: opportunities and challenges. Academy of Management Journal, 50(1), 20-24.

Vega, G. (2015) The Case Writing Workbook: a self-guided workshop, New York, NY: Routledge.

Yin, R.K. (1994) Case Study Research: design \& methods. California: Sage Publications 